\title{
Relation between cytokine promoter gene polymorphism and toxicity of 5-fluorouracil plus cisplatin chemotherapy
}

\author{
KAZUHIKO SAKAMOTO ${ }^{1}$, MASAAKI OKA ${ }^{1}$, SHIGEHUMI YOSHINO ${ }^{1}$, SHOICHI HAZAMA ${ }^{1}$, \\ TOSHIHIRO ABE ${ }^{1}$, NAOKO OKAYAMA ${ }^{2}$ and YUJI HINODA ${ }^{2,3}$
}

\begin{abstract}
Department of ${ }^{1}$ Surgery II, ${ }^{2}$ Division of Laboratory and ${ }^{3}$ Department of Clinical Laboratory Science, Yamaguchi University School of Medicine and Yamaguchi University Hospital, 1-1-1 Minami-Kogushi, Ube, Yamaguchi 755-8505, Japan
\end{abstract}

Received January 24, 2006; Accepted March 21, 2006

\begin{abstract}
Variability in the efficacies and toxicities of anticancer agents is a major problem. We hypothesized that polymorphisms in cytokine gene promoters may underlie genetic susceptibility to chemotherapy-induced toxicities in the Japanese. DNA was extracted from 100 patients undergoing 5-fluorouracil plus cisplatin chemotherapy. We used a caseonly design to evaluate the relation between toxicities and cytokine promoter gene polymorphisms. The following polymorphisms were genotyped: tumor necrosis factor (TNF)- $\alpha-$ 1031T/C, interleukin (IL)-1ß-511C/T, IL-6-634C/G, IL-10$819 \mathrm{~T} / \mathrm{C}$, IL-18-137G/C , macrophage migration inhibitory factor -173G/C, and 86-basepair variable numbers of tandem repeat in intron 2 of the IL-1 receptor antagonist. The frequency of the IL-6-634 GC and GG genotypes was significantly higher in patients with grades 1-4 leukopenia $(\mathrm{P}=0.003$; Crude-odds ratios $(\mathrm{Cr}-\mathrm{OR})=4.0$ ), neutropenia $(\mathrm{P}=0.0051 ; \mathrm{Cr}-\mathrm{OR}=3.6)$, or thrombocytopenia $(\mathrm{P}<0.0001 ; \mathrm{Cr}-\mathrm{OR}=6.1)$ than in patients without these toxicities. Similarly, the frequency of the IL-1ß511 TC and TT genotypes and the frequency of the TNF- $\alpha-$ 1031 TT genotype were significantly higher in patients with grades 1-4 thrombocytopenia $(\mathrm{P}=0.015 ; \mathrm{Cr}-\mathrm{OR}=2.9)$ and stomatitis $(\mathrm{P}=0.02$; $\mathrm{Cr}-\mathrm{OR}=3.1)$, respectively. Multivariate analysis of factors such as age, sex, disease type, purpose of the chemotherapy, use of radiotherapy, and cytokine promoter gene polymorphisms showed polymorphisms to be significant predictors of toxicity. Our results suggest that polymorphisms in cytokine gene promoters may be associated with susceptibilities to leukopenia, neutropenia, thrombocytopenia and stomatitis in patients treated with 5-fluorouracil plus cisplatin.
\end{abstract}

Correspondence to: Dr Masaaki Oka, Department of Surgery II, Yamaguchi University School of Medicine, 1-1-1 Minami-Kogushi, Ube, Yamaguchi 755-8505, Japan

E-mail: 2geka-1@yamaguchi-u.ac.jp

Key words: IL-6-634 C/G polymorphism, IL-1ß-511 C/T polymorphism, TNF- $\alpha-1031 \mathrm{~T} / \mathrm{C}$ polymorphism

\section{Introduction}

Variability in the efficacy and toxicity of anticancer agents in patients is a major problem in clinical practice. Such variability is largely due to genetic factors leading to altered drug metabolism or receptor expression (1). It has been reported that the polymorphisms in genes encoding drug-metabolizing enzymes, which are more numerous than those in genes encoding receptors, alter the pharmacokinetics of therapeutic agents (2-4). Tailored chemotherapies based on such genetic variations have great potential to improve cancer treatment.

5-Fluorouracil (5-FU) remains one of the most frequently prescribed chemotherapeutic drugs for treatment of cancers of the gastrointestinal tract, breast, head and neck. 5-FU plus cisplatin (CDDP) therapy, which consists of continuous infusion of 5-FU and drip infusion of low-dose CDDP, has been used to treat advanced gastrointestinal carcinoma (5-7). The combination of 5-FU plus CDDP, producing biochemical modulation, is recognized as an effective regimen (8). It is suggested that CDDP enhances 5-FU cytotoxicity for cancer cell lines, by inhibiting intracellular l-methionine metabolism and increasing the intracellular levels of folates for the reduced foliate pool. The combined rates of complete and partial response are reported to be approximately $50-60 \%$ in gastrointestinal carcinoma, and severe toxicities (grades 3-4) are reported to occur at a rate of $3-11 \%$. No death from toxicity has been noted $(9,10)$.

A pharmacogenetic disorder has recently been described in cancer patients with complete or partial deficiency of dihydropyrimidine dehydrogenase (DPD), which metabolizes 5-FU, the patients suffer from severe or even life-threatening toxicity after administration of 5-FU. It was found that a number of these patients were heterozygous for a mutant DPD allele (11-13). However, the frequency of mutant DPD alleles (frame-shift or missense mutation) was only 5.6\%, and these alleles were not associated with increased toxicity of 5-FU in a Japanese population (14). The efficacy of genotyping this polymorphism in the 5-FU metabolizing enzyme to predict 5-FU toxicity in Japanese has not been reported.

When the body is stressed, various cytokines are produced. Typical cytokines, such as tumor necrosis factor (TNF)- $\alpha$, interleukin (IL)-1ß, IL-1 receptor antagonist (RA), IL-6, IL-10, IL-18, and macrophage migration inhibitory factor (MIF), exhibit a variety of inflammatory, hematopoietic and immuno- 
logical regulatory activities (15-19). It has been reported that levels of cytokine production are influenced by polymorphisms in the promoters of cytokine genes $(20,21)$. Brull et al (22) reported that the IL-6-174 polymorphism affects IL-6 production after coronary artery bypass surgery, suggesting that genetics may influence IL-6 levels after acute severe injury. Chemotherapy also stresses the body. It is reported that serum levels of cytokines increase during chemotherapy (23-26). The onset of toxicity related to chemotherapy may also be affected by cytokine promoter gene polymorphisms. Thus, cytokine production may be related to recovery from manifestations of toxicity such as leukopenia. Therefore, we hypothesized that these cytokine promoter gene polymorphisms may be responsible, in part, for genetic susceptibilities to the toxic effects of chemotherapy.

\section{Materials and methods}

Patients. One hundred patients who underwent chemotherapy between 1997 and 2004 in the Department of Surgery II at Yamaguchi University School of Medicine were investigated. Chemotherapy was performed to prevent recurrence after surgery or progression or recurrence of gastrointestinal malignancy. Chemotherapy was combined with radiotherapy to increase effectiveness on a case-by-case basis. The patients ranged in age from 27 to 83 years (mean 63.0 years). Patient characteristics are listed in Table I. The National Cancer Institute - The Common Toxicity Criteria (NCI-CTC) was used to evaluate the toxicity of chemotherapy. Toxicities were evaluated when symptoms of the highest grades of toxicity appeared during or after chemotherapy.

Written informed consent was obtained from all study patients. The study protocol was approved by the Institutional Review Board for the Use of Human Subjects at Yamaguchi University School of Medicine.

Treatment regimen. Chemotherapy comprised the following: $5-\mathrm{FU}$ plus CDDP therapy consisting of 5-FU at $330 \mathrm{mg} / \mathrm{m}^{2} /$ day administered by continuous intravenous infusion on days 1-7 and CDDP at $6 \mathrm{mg} / \mathrm{m}^{2} /$ day administered intravenously for $2 \mathrm{~h}$ by drip infusion on days 1-5. Prior to administration of CDDP, 5-HT3-receptor antagonist was orally or intravenously administered. This regimen was repeated for 4 weeks. However, when symptoms of grade 3 or 4 toxicity appeared during chemotherapy, the chemotherapy was stopped.

DNA specimens. For DNA analysis, $7 \mathrm{ml}$ of peripheral blood was obtained from 78 patients. DNA was isolated by a conventional $\mathrm{NaI}$ method (27) and stored at $4^{\circ} \mathrm{C}$. Because we could not obtain peripheral blood from 22 patients, DNA was extracted from the non-cancerous portion of each frozen resected specimen with a HighPure ${ }^{\mathrm{TM}}$ PCR Template Preparation Kit (Roche, Germany).

Genotyping. The region of intron 2 of the IL-1RA gene that contains the 86 basepair (bp) variable numbers of tandem repeat (VNTR), was amplified by polymerase chain reaction (PCR) with primers 5'-CCTCAGCAACACTCCTATTGAC3' and 5'-GGTCTCATCTTCCTGGTCTGC-3'. Amplification conditions were an initial denaturation at $95^{\circ} \mathrm{C}$ for $2 \mathrm{~min}$
Table I. Patient characteristics (total=100).

\begin{tabular}{|c|c|}
\hline \multicolumn{2}{|l|}{ Age (years) } \\
\hline Mean & $63.1 \pm 1.0$ \\
\hline Range & $27-83$ \\
\hline \multicolumn{2}{|l|}{ Sex } \\
\hline Male & 85 \\
\hline Female & 15 \\
\hline \multicolumn{2}{|l|}{ Disease type } \\
\hline Esophageal cancer & 64 \\
\hline Gastric cancer & 13 \\
\hline Hepatocellular carcinoma & 9 \\
\hline Rectal cancer & 4 \\
\hline Cholangicellular carcinoma & 3 \\
\hline Bile duct cancer & 2 \\
\hline Colon cancer & 2 \\
\hline Pancreatic cancer & 2 \\
\hline Gall bladder cancer & 1 \\
\hline \multicolumn{2}{|l|}{ Purpose of chemotherapy } \\
\hline Adjuvant case & 39 \\
\hline Progress/Recurrent case & 61 \\
\hline \multicolumn{2}{|l|}{ Use of radiotherapy } \\
\hline+ & 19 \\
\hline- & 81 \\
\hline \multicolumn{2}{|l|}{ Body-surface area $\left(\mathrm{m}^{2}\right)$} \\
\hline Mean & $1.59 \pm 0.01$ \\
\hline Range & $1.1-1.9$ \\
\hline \multicolumn{2}{|l|}{ Chemotherapy } \\
\hline CDDP (mg/body/day) & $8.6 \pm 0.2$ \\
\hline 5-FU (mg/body/day) & $458 \pm 9.0$ \\
\hline
\end{tabular}

Values indicated are the mean \pm standard error.

followed by 26 cycles of denaturation at $94^{\circ} \mathrm{C}$ for $30 \mathrm{sec}$, annealing at $61^{\circ} \mathrm{C}$ for $20 \mathrm{sec}$, and elongation at $72^{\circ} \mathrm{C}$ for $30 \mathrm{sec}$. The PCR products of $423 \mathrm{bp}$ (four repeats of the $86 \mathrm{bp}$ region), $251 \mathrm{bp}$ (two repeats), $509 \mathrm{bp}$ (five repeats) and $337 \mathrm{bp}$ (three repeats) were analyzed by electrophoresis on $2 \%$ agarose gels containing $0.1 \%$ ethidium bromide (28) and visualized by ultra violet (UV) illumination.

TNF- $\alpha$, IL-1ß, IL-6, IL-10, IL-18 and MIF gene promoter polymorphisms were identified with the tetra-primer amplification refractory mutation system (ARMS)-PCR (29-31). Four primers, forward primer (FO), reverse primer (RO), forward inner primer $(\mathrm{FI})$, and reverse inner primer (RI), were used for detection of each polymorphism. Allele specificity was conferred by a mismatch between the 3'-terminal base of the inner primer and the template and a second deliberate mismatch at position-2 from the 3'-terminus of the inner primer. Each PCR reaction was carried out in a total volume of $10 \mu \mathrm{l}$ containing $80 \mathrm{ng} / \mu 1 \mathrm{DNA}$ template, $10 \mathrm{pmol} / \mu \mathrm{l}$ each primers, $200 \mu \mathrm{M}$ 
Table II. Primers and other conditions of tetra-primer ARMS-PCR in this study.

\begin{tabular}{|c|c|c|c|c|c|c|}
\hline \multirow[b]{2}{*}{ SNP } & \multirow[b]{2}{*}{ Primer } & \multirow[b]{2}{*}{ Primer sequence } & \multicolumn{4}{|c|}{ Tetra-primer ARMS-PCR } \\
\hline & & & $\begin{array}{c}\mathrm{Tm} \\
\text { of primer }\end{array}$ & $\begin{array}{c}\text { Primer } \\
\text { condition } \\
(\mathrm{pmol} / \mu \mathrm{l})\end{array}$ & $\begin{array}{c}\text { Annealing } \\
\text { temperature }\left({ }^{\circ} \mathrm{C}\right) \\
\text { (no. of cycles) }\end{array}$ & $\begin{array}{l}\text { Amplicon } \\
\text { size (bp) }\end{array}$ \\
\hline TNF- $\alpha$ & FO & 5'-gctgtggggagaacaaaaggataa-3' & 64.6 & 4 & $59(10)$ & 278 (outer) \\
\hline \multirow[t]{3}{*}{-1031} & RO & 5'-ggtccccatactcgacttccata-3' & 63.3 & 2 & $56(25)$ & 189 ( $\mathrm{T}$ allele $)$ \\
\hline & FI & 5'-gaagcaaaggagaagctgagaacat-3' & 63.5 & 8 & & $136(\mathrm{C}$ allele $)$ \\
\hline & RI & 5'-tccagaccctgacttttcctgcg-3' & 69 & 20 & & \\
\hline IL-1ß & $\mathrm{FO}$ & 5 '-atctggcattgatctggttcatcc-3' & 65.5 & 8 & $65(10)$ & 313 (outer) \\
\hline \multirow[t]{3}{*}{-511} & RO & $5^{\prime}$-cttaactttaggaatcttcccactt-3' & 57.5 & 8 & $57(25)$ & 141 (C allele) \\
\hline & FI & 5'-cctgcaattgacagagagctacc-3' & 62.4 & 20 & & 217 ( $\mathrm{T}$ allele $)$ \\
\hline & RI & 5'-cttgggtgctgttctctgccgca-3' & 73 & 1 & & \\
\hline IL-6 & FO & 5'-acctggagacgccttgaagtaact-3' & 63.7 & 4 & $60(30)$ & 186 (outer) \\
\hline \multirow[t]{3}{*}{-634} & RO & 5'-aaaccaaagatgttctgaactgagt-3' & 59.5 & 10 & & 144 (C allele) \\
\hline & FI & 5'-gccaggcagtctacaacaggcc-3' & 67.5 & 10 & & 86 (G allele) \\
\hline & RI & 5'-gtgttctggctctccetgtgtgc-3' & 67.8 & 4 & & \\
\hline IL-10 & FO & 5'-acactactaaggcttctttggga-3' & 58.3 & 10 & $59(31)$ & 383 (outer) \\
\hline \multirow[t]{3}{*}{-819} & RO & $5^{\prime}$-tgcacttgctgaaagcttcttat-3' & 60.4 & 10 & & 121 (T allele) \\
\hline & FI & 5'-tgtaccettgtacaggtgatgtcat-3' & 61.7 & 10 & & 309 (C allele) \\
\hline & RI & 5'-gagcaaactgaggcacagaggtg-3' & 65.7 & 10 & & \\
\hline IL-18 & FO & 5'-agatgcttctaatggactaaggag-3' & 55.8 & 4 & $56(36)$ & 342 (outer) \\
\hline \multirow[t]{3}{*}{-137} & RO & 5'-ggcaaaatgcactgggagacaat-3' & 66.5 & 4 & & 257 (G allele) \\
\hline & FI & 5'-gccccaacttttacggaagaatag-3' & 63.1 & 2 & & 135 (C allele) \\
\hline & RI & 5'-atgtaatatcactattttcatgaactg-3' & 54.8 & 30 & & \\
\hline MIF & FO & 5'-cagtgcgtgcagtggaatgaac-3' & 66.2 & 2 & $61(33)$ & 298 (outer) \\
\hline \multirow[t]{3}{*}{-173} & RO & 5'-tggggaagtcaccgectgcet-3' & 72.6 & 2 & & 126 (G allele) \\
\hline & FI & 5'-agccgccaagtggagaactgg-3' & 68.1 & 2 & & 213 (C allele) \\
\hline & RI & $5^{\prime}$-agcccggcgcaccgctcctag-3' & 75.6 & 6 & & \\
\hline
\end{tabular}

Tm, melting temperature.

dNTP, 2 mM $\mathrm{MgCl}_{2}, 20 \mathrm{mM}$ Tris-HCl (pH 8.0), $100 \mathrm{mM}$ $\mathrm{KCl}$ and $1 \mathrm{U}$ Taq polymerase (Takara Ex Taq, Takara, Tokyo, Japan). The solution was overlaid with $10 \mu 1$ mineral oil. Amplification conditions were $2 \mathrm{~min}$ at $95^{\circ} \mathrm{C}$ followed by 30 cycles of denaturation at $95^{\circ} \mathrm{C}$ for $30 \mathrm{sec}$ annealing at $60^{\circ} \mathrm{C}$ for $20 \mathrm{sec}$ and extension at $72^{\circ} \mathrm{C}$ for $30 \mathrm{sec}$. Reactions were amplified with a Robocycler (Gene Amp PCR System 9600, Perkin-Elmer, Tokyo, Japan). The concentration of each primer, number of cycles, and annealing temperature were evaluated and optimized for each single nucleotide polymorphism (SNP) and are shown in Table II. Hot-start PCR (Takara Ex Taq, Hot Start Version) was performed for the IL-1ß and MIF gene polymorphisms. PCR products were separated by electrophoresis on $2.0 \%$ agarose gels, stained with ethidium bromide, and visualized by UV illumination.

Statistical analysis. Values are presented as mean \pm standard error. Differences in the distribution of genotypes or alleles were analyzed by $\chi^{2}$ test. Because homozygotes for the rare allele were too few to perform a $2 \times 3 \chi^{2}$ test, homozygotes of the dominant allele and variant carriers were compared by $2 \times 2 \chi^{2}$ test. Variables that were potentially predictive of chemotherapy-related toxicity were then entered into a multivariate logistic regression model. Odds ratios (OR) and 95\% confidence interval $(\mathrm{CI})$ were also calculated. With respect to $\mathrm{OR}$ for polymorphisms, crude $(\mathrm{Cr})-\mathrm{OR}$ were calculated by univariate analysis of toxicity and adjusted (Ad)-OR were calculated by multivariate analysis of variables. A P-value of $<0.05$ was considered statistically significant. All analyses were performed with StatView statistical software (version 5.0; SAS Institute, Inc., Cary, NC).

\section{Results}

Toxicity. Toxicities in patients treated with chemotherapy are shown in Table III. The incidences of grades 3-4 toxicities 
Table III. Toxicity profile of patients treated with chemotherapy.

\begin{tabular}{lrrrrr}
\hline & \multicolumn{5}{c}{ Grade } \\
\cline { 2 - 6 } & 0 & 1 & 2 & 3 & 4 \\
\hline Hemoglobin & 30 & 41 & 23 & 6 & 0 \\
Leukocyte & 31 & 21 & 25 & 19 & 4 \\
Neutrophil & 36 & 14 & 19 & 18 & 13 \\
Thrombocyte & 46 & 36 & 15 & 3 & 0 \\
Bilirubin & 96 & 1 & 2 & 1 & 0 \\
GOT/GPT & 73 & 22 & 4 & 1 & 0 \\
Creatinine & 83 & 15 & 2 & 0 & 0 \\
Stomatitis & 60 & 16 & 16 & 6 & 2 \\
Vomiting & 60 & 22 & 14 & 1 & 3 \\
Diarrhea & 65 & 19 & 9 & 7 & 0 \\
Anorexia & 18 & 22 & 27 & 6 & 27 \\
Fever & 83 & 16 & 1 & 0 & 0 \\
Allergy & 94 & 6 & 0 & 0 & 0 \\
Hair loss & 94 & 5 & 1 & 0 & 0 \\
\hline
\end{tabular}

The table represents the no. of patients suffering from a particular type of toxicity (graded according to NCI-CTC). presenting as leukopenia, neutropenia and anorexia were $23.0,31.0$ and $33.0 \%$, respectively. Other types of severe toxicity occurred in a few patients.

Relation between genetic polymorphisms and toxicity. Among the cytokine promoter gene polymorphisms analyzed, significant association with chemotherapeutic toxicities, including leukopenia, neutropenia, thrombocytopenia and stomatitis, was found for IL-6-634C/G, IL-1ß-511C/T and TNF- $\alpha-1031 \mathrm{~T} / \mathrm{C}$ (Table IV). The combined frequency of the IL-6-634 GC and GG genotypes was significantly higher in patients with grades 1-4 leukopenia $(\mathrm{P}=0.003 ; \mathrm{Cr}-\mathrm{OR}=4.0 ; 95 \% \mathrm{CI}=1.5-10)$, neutropenia $(\mathrm{P}=0.0051 ; \mathrm{Cr}-\mathrm{OR}=3.6 ; 95 \% \mathrm{CI}=1.5-8.9)$, and thrombocytopenia $(\mathrm{P}<0.0001 ; \mathrm{Cr}-\mathrm{OR}=6.1 ; 95 \% \mathrm{CI}=2.5-14)$ than in patients without these manifestations of toxicity (Table V). Similarly, a significant association between genotype frequency and toxicity was observed for the IL-1ß-511 TC and TT genotypes and grades 1-4 of thrombocytopenia ( $\mathrm{P}=0.015$; $\mathrm{Cr}-\mathrm{OR}=2.9 ; 95 \% \mathrm{CI}=1.2-7.0)$ and the TNF- $\alpha-1031$ TT genotype and grades $1-4$ of stomatitis $(\mathrm{P}=0.02 ; \mathrm{Cr}-\mathrm{OR}=3.1 ; 95 \%$ $\mathrm{CI}=1.2-8.3)$.

Because the toxicity of chemotherapy is considered serious when the grade is higher than 3 , we divided patients into two groups on the basis of toxicity grade (grades $0-2$ and grades $3-4)$, and examined the relation between toxicity grade and

Table IV. Relationship between genetic polymorphism and toxicity.

\begin{tabular}{|c|c|c|c|c|c|c|c|c|c|c|c|c|}
\hline & \multicolumn{3}{|c|}{$\begin{array}{l}\text { Leukopenia } \\
\text { Grade }\end{array}$} & \multicolumn{3}{|c|}{$\begin{array}{l}\text { Neutropenia } \\
\text { Grade }\end{array}$} & \multicolumn{3}{|c|}{$\begin{array}{c}\text { Thrombocytopenia } \\
\text { Grade }\end{array}$} & \multicolumn{3}{|c|}{$\begin{array}{l}\text { Stomatitis } \\
\text { Grade }\end{array}$} \\
\hline & 0 & $1-4$ & $\mathrm{P}$ & 0 & $1-4$ & $\mathrm{P}$ & 0 & $1-4$ & $\mathrm{P}$ & 0 & $1-4$ & $\mathrm{P}$ \\
\hline \multicolumn{13}{|c|}{ TNF- $\alpha-1031$} \\
\hline $\mathrm{CC}+\mathrm{CT}$ & 9 & 22 & & 11 & 20 & & 14 & 17 & & 24 & 7 & \\
\hline $\mathrm{TT}$ & 22 & 47 & & 25 & 44 & & 32 & 37 & & 36 & 33 & 0.05 \\
\hline \multicolumn{13}{|l|}{ IL-1ß-511 } \\
\hline $\mathrm{CC}$ & 11 & 22 & & 13 & 20 & & 21 & 12 & & 18 & 15 & \\
\hline $\mathrm{CT}+\mathrm{TT}$ & 20 & 47 & & 23 & 44 & & 25 & 42 & 0.05 & 42 & 25 & \\
\hline \multicolumn{13}{|l|}{ IL-6-634 } \\
\hline $\mathrm{CC}$ & 24 & 32 & & 27 & 29 & & 36 & 20 & & 30 & 26 & \\
\hline $\mathrm{CG}+\mathrm{GG}$ & 7 & 37 & 0.05 & 9 & 35 & 0.05 & 10 & 34 & 0.05 & 30 & 14 & \\
\hline \multicolumn{13}{|l|}{ IL-10-819 } \\
\hline $\mathrm{CC}+\mathrm{CT}$ & 18 & 37 & & 21 & 34 & & 25 & 30 & & 35 & 20 & \\
\hline TT & 13 & 32 & & 15 & 30 & & 21 & 24 & & 25 & 20 & \\
\hline \multicolumn{13}{|l|}{ IL-18-137 } \\
\hline CG & 8 & 13 & & 9 & 12 & & 12 & 9 & & 15 & 6 & \\
\hline GG & 23 & 56 & & 27 & 52 & & 34 & 45 & & 45 & 34 & \\
\hline \multicolumn{13}{|l|}{ MIF-173 } \\
\hline $\mathrm{CC}+\mathrm{CG}$ & 9 & 22 & & 10 & 21 & & 14 & 17 & & 16 & 15 & \\
\hline GG & 22 & 47 & & 26 & 43 & & 32 & 37 & & 44 & 25 & \\
\hline
\end{tabular}

$\chi^{2}$ test was used to elucidate differences. 
Table V. Univariate and multivariate logistic regression analysis of toxicities (grade 0 vs. grades 1-4).

\begin{tabular}{|c|c|c|c|c|c|c|c|c|c|c|c|c|c|c|c|c|}
\hline & \multicolumn{4}{|c|}{ Leukopenia } & \multicolumn{4}{|c|}{ Neutropenia } & \multicolumn{4}{|c|}{ Thrombocytopenia } & \multicolumn{4}{|c|}{ Stomatitis } \\
\hline & $\begin{array}{c}\text { Uni } \\
\mathrm{P}\end{array}$ & $\begin{array}{l}\mathrm{Cr}-\mathrm{OR} \\
95 \% \mathrm{CI}\end{array}$ & $\begin{array}{c}\text { Multi } \\
\text { P }\end{array}$ & $\begin{array}{l}\text { Ad-OR } \\
95 \% \text { CI }\end{array}$ & $\begin{array}{c}\text { Uni } \\
\mathrm{P}\end{array}$ & $\begin{array}{l}\mathrm{Cr}-\mathrm{OR} \\
95 \% \mathrm{CI}\end{array}$ & $\begin{array}{c}\text { Multi } \\
\text { P }\end{array}$ & $\begin{array}{l}\text { Ad-OR } \\
95 \% \text { CI }\end{array}$ & $\begin{array}{c}\text { Uni } \\
\mathrm{P}\end{array}$ & $\begin{array}{c}\mathrm{Cr}-\mathrm{OR} \\
95 \% \mathrm{CI}\end{array}$ & $\begin{array}{c}\text { Multi } \\
\text { P }\end{array}$ & $\begin{array}{l}\text { Ad-OR } \\
95 \% \text { CI }\end{array}$ & $\begin{array}{c}\text { Uni } \\
\mathrm{P}\end{array}$ & $\begin{array}{c}\mathrm{Cr}-\mathrm{OR} \\
95 \% \mathrm{CI}\end{array}$ & $\begin{array}{c}\text { Multi } \\
\text { P }\end{array}$ & $\begin{array}{l}\text { Ad-OR } \\
95 \% \mathrm{CI}\end{array}$ \\
\hline Age & 0.54 & 1.3 & 0.86 & 1.1 & 0.65 & 1.2 & 0.99 & 1.0 & 0.34 & 1.5 & 0.45 & 0.67 & 0.62 & 0.8 & 0.75 & 0.87 \\
\hline$\leq 63$ vs. $>63$ & & $0.6-3.1$ & & $0.4-2.9$ & & $0.5-2.7$ & & $0.4-2.5$ & & $0.7-3.2$ & & $0.2-1.9$ & & $0.4-1.8$ & & $0.4-2.1$ \\
\hline Sex & 0.69 & 0.8 & 0.64 & 0.71 & 0.41 & 0.6 & 0.3 & 0.48 & 0.08 & 2.7 & 0.13 & 3.0 & 0.57 & 1.4 & 0.73 & 1.2 \\
\hline Male vs. female & & $0.2-2.7$ & & $0.2-3.0$ & & $0.2-2.1$ & & $0.1-7.0$ & & $0.9-8.7$ & & $0.7-12$ & & $0.4-4.5$ & & $0.3-4.5$ \\
\hline Disease type & 0.2 & 0.6 & 0.99 & 1.0 & 0.19 & 0.6 & 0.74 & 0.83 & 0.31 & 0.7 & 0.69 & 1.3 & 0.86 & 0.9 & 0.69 & 1.2 \\
\hline $\begin{array}{l}\text { Others vs. eso- } \\
\text { phageal cancer }\end{array}$ & & $0.2-1.4$ & & $0.3-3.2$ & & $0.2-1.3$ & & $0.3-2.6$ & & $0.3-1.5$ & & $0.4-4.4$ & & $0.4-2.1$ & & $0.4-3.8$ \\
\hline $\begin{array}{l}\text { Purpose of } \\
\text { chemotherapy }\end{array}$ & 0.35 & 0.7 & 0.51 & 0.67 & 0.38 & 0.7 & 0.53 & 0.69 & 0.12 & 0.5 & 0.41 & 0.6 & 0.56 & 0.8 & 0.4 & 0.64 \\
\hline $\begin{array}{l}\text { Progress/recurrent } \\
\text { vs. adjuvant }\end{array}$ & & $0.3-1.6$ & & $0.2-2.2$ & & $0.3-1.6$ & & $0.2-2.2$ & & $0.2-1.2$ & & $0.2-2.0$ & & $0.3-1.8$ & & $0.2-1.8$ \\
\hline Use of radiotherapy & $<0.01$ & 10 & 0.03 & 10 & $<0.01$ & 6.1 & 0.04 & 5.7 & 0.16 & 2.1 & 0.04 & 5.1 & 0.75 & 0.8 & 0.6 & 1.4 \\
\hline +vs. - & & $1.3-83$ & & $1.2-95$ & & $1.3-28$ & & $1.1-30$ & & $0.7-6.1$ & & $1.1-24$ & & $0.3-2.4$ & & $0.4-4.8$ \\
\hline IL-6-634 & $<0.01$ & 4.0 & 0.02 & 3.4 & $<0.01$ & 3.6 & 0.02 & 3.2 & $<0.01$ & 6.1 & $<0.01$ & 6.6 & & & & \\
\hline $\mathrm{CG}+\mathrm{GG}$ vs. $\mathrm{CC}$ & & $1.5-10$ & & $1.2-9.7$ & & $1.5-8.9$ & & $1.2-8.4$ & & $2.5-14$ & & $2.4-18$ & & & & \\
\hline IL-1ß-511 & & & & & & & & & 0.013 & 2.9 & $<0.01$ & 5.1 & & & & \\
\hline $\mathrm{CT}+\mathrm{TT}$ vs. $\mathrm{CC}$ & & & & & & & & & & $1.2-7.0$ & & $1.6-16$ & & & & \\
\hline TNF- $\alpha-1031$ & & & & & & & & & & & & & 0.02 & 3.1 & 0.02 & 3.3 \\
\hline TT vs. $\mathrm{CC}+\mathrm{CT}$ & & & & & & & & & & & & & & $1.2-8.3$ & & $1.2-9.2$ \\
\hline
\end{tabular}

Uni, univariate analysis; Cr-OR, crude odds ratios; Multi, multivariate analysis; Ad-OR, adjusted odds ratios.

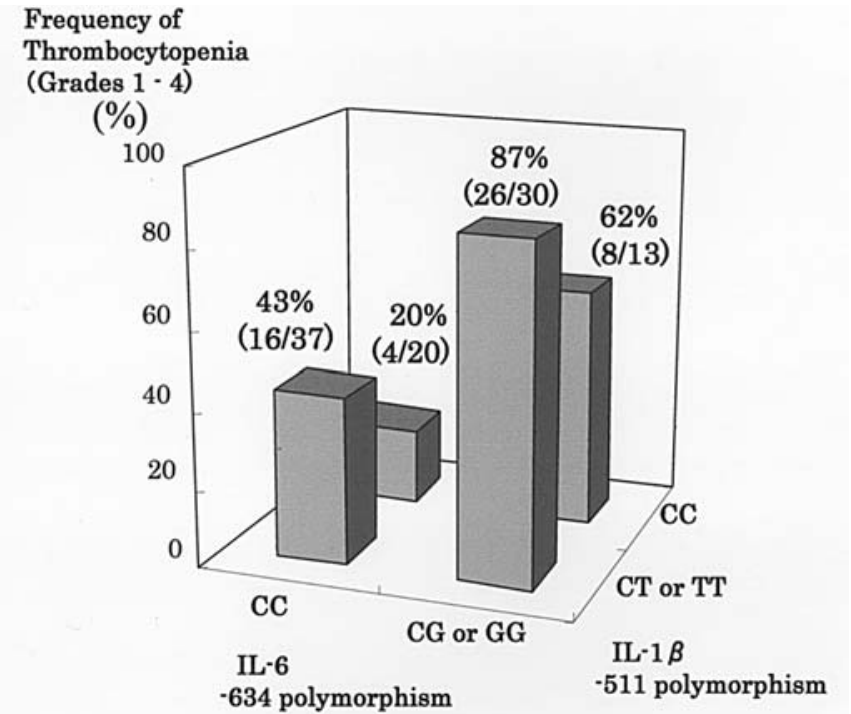

Figure 1. Relations of IL-1ß-511 C/T and IL-6-634 G/C polymorphisms to thrombocytopenia. Patients who carried both the IL-1ß-511 $\mathrm{T}$ allele and the IL-6-634 G allele developed thrombocytopenia at a higher frequency (87\%) than that of patients who did not carry both of these alleles $(20 \%)$.

cytokine promoter gene polymorphisms. We found that the combined frequency of the IL-6-634 GC and GG genotypes was significantly higher in patients with grades 3-4 neutro- penia than in those with grades $0-2$ neutropenia $(\mathrm{P}=0.019$; $\mathrm{Cr}-\mathrm{OR}=4.2 ; 95 \% \mathrm{CI}=1.7-10)$.

Clinicopathological variables, including age ( $>63$ or $\leq 63$ years), sex, type of disease (esophageal cancer or other), purpose of chemotherapy (whether as adjuvant therapy or for progressive or recurrent disease), use of radiotherapy and cytokine promoter gene polymorphisms (TNF- $\alpha, \mathrm{IL}-1 \beta$ and IL-6) were entered into a multivariate logistic regression model to identify factors influencing toxicities (leukopenia, neutropenia, thrombocytopenia and stomatitis) (Table V). Cytokine promoter gene polymorphisms were significantly associated with the toxicities, respectively.

Thrombocytopenia (grades 1-4) was associated with both the IL-1ß-511 and IL-6-634 polymorphisms. When thrombocytopenia was analyzed with respect to these polymorphisms together, the occurrence rate was $87 \%$ in patients with both the IL-1ß-511 CT or TT genotype and the IL-6-634 CG or GG genotype. In contrast, the occurrence rate was only $20 \%$ in patients with both the IL-1ß-511 CC genotype and the IL-6634 CC genotype (Fig. 1).

\section{Discussion}

This is the first report of the significance of cytokine promoter gene polymorphisms for predicting chemotherapy-related toxicities. We compared polymorphisms in genes encoding several 
cytokines between patients treated with 5-FU and CDDP who did and did not develop toxicity. The IL-1B-511 T allele, IL-6$634 \mathrm{G}$ allele and TNF- $\alpha-1031 \mathrm{~T}$ allele were associated with development of thrombocytopenia (IL-1ß and IL-6), leukopenia (IL-6), neutropenia (IL-6) and stomatitis (TNF- $\alpha$ ). Thrombocytopenia occurred in 26 of 30 (87\%) patients having both the IL-1ß-511 T allele and IL-6-634 G allele. Hematologic toxicity is a common complication of radiotherapy and has been shown to occur more frequently in patients who received chemotherapy combined with radiotherapy (32). As expected, in the present study, radiotherapy was identified by multivariate analysis as a hematologic risk factor. Cytokine promoter gene polymorphisms were also found to be risk factors for development of toxicity.

Leukopenia and neutropenia are the critical chemotherapyrelated toxicities. There have been no reports of the relation between cytokine promoter gene polymorphisms and leukopenia. Regulation of leukocytosis appears to be controlled by an array of hematopoietic growth factors. During hematopoietic recovery after chemotherapy-induced myelosuppression, serum IL-6 levels are increased to prevent myelosuppression or to accelerate recovery $(24,25)$. IL-6 is a pleiotropic cytokine involved in the regulation of the acute phase reaction, immune responses, bone resorption, and support of formation of multipotential colonies by hematopoietic stem cells. Although IL-6 acts as a hematopoietic factor in myelosuppression, it also acts to delay apoptosis of neutrophils (33). The sequence around position -634 in the IL-6 gene regulatory region, which was examined in this study, does not show strong homology to any known transcription factor-binding site, however, there is a potential glucocorticoid receptor element at position -557 to -552 (34). Ferrari et al (21) reported that the IL-6-634 C allele showed increased promoter activity in response to IL-1 $\beta$ or TNF- $\alpha$ in the presence of dexamethasone in transfected cells. Leukocytosis of bone marrow stem cells and delayed apoptosis of neutrophils may vary with respect to the level of IL-6 pro-duction at the time of the chemotherapy. The IL-6$634 \mathrm{C}$ allele, which shows higher transcriptional activity than the $\mathrm{G}$ allele, may play a protective role against leukopenia caused by chemo-therapy.

Thrombocytopenia is another manifestation of chemotherapy-related toxicity. IL-6 plays a regulatory role in thrombocytosis (35). There are reports that thrombocytosis induced by IL-1ß is mediated by IL-6 $(36,37)$. With respect to the relation between platelet counts and cytokine promoter gene polymorphisms, Fernandez-Real et al (38) reported that the basal platelet count in healthy persons is partially dependent on the allele of the IL-6-174 polymorphism. The IL-6$174 \mathrm{G}$ allele has higher transcriptional activity than the $\mathrm{C}$ allele in vitro (39). Basal platelet counts are also high in normal persons with the $\mathrm{G}$ allele (38). In the present study, the frequency of thrombocytopenia was lower in patients with the IL-6-634 CC genotype, which shows higher transcriptional activity, than those with the GC and GG genotypes. The IL-1ß511 polymorphism was also associated with thrombocytopenia. However, there is no significant data on the effect of specific allele of the -511 polymorphism on production of IL-1ß (40).

Chemotherapy-induced stomatitis is an important, doselimiting, and costly side effect of cancer therapy. Some degree of stomatitis occurs in approximately $40 \%$ of patients who receive anticancer chemotherapy (41). Stomatitis results from the direct inhibitory effects of the chemotherapy on DNA replication and mucosal cell proliferation $(42,43)$. Chemotherapy affects the release of proinflammatory cytokines from the epithelium (44). TNF- $\alpha$ is a key proinflammatory cytokine that can cause tissue damage and release of TNF- $\alpha$ may initiate and/or accelerate development of stomatitis (45). In patients with recurrent aphthous stomatitis (RAS), high levels of TNF- $\alpha$ have been detected in biopsy specimens of ulcer tissue (46). In addition, circulating leukocytes from RAS patients secrete higher levels of TNF than leukocytes from control subjects (47). Transcriptional activity of the TNF- $\alpha-1031 \mathrm{C}$ allele in response to concanavalin A (Con A) was two times greater than that of the dominant $\mathrm{T}$ allele (20). In our result, however, the frequency of the TNF- $\alpha-1031$ TT genotype was significantly high in patients with stomatitis. There is a discrepancy between our result and the reported promoter activities of the TNF- $\alpha-1031$ polymorphism. Bazrafshani et al (49) reported that there was no significant relation between the susceptibility to RAS and the TNF- $\alpha-308$ polymorphism, although the transcriptional activity of TNF- $\alpha-308$ A allele was high. Further studies are needed to confirm the relation between TNF- $\alpha$ promoter polymorphism and stomatitis.

In the present study, we found that specific cytokine promoter gene polymorphisms influence the susceptibility of patients to chemotherapy-induced toxicity. Polymorphisms in drug-metabolizing enzymes may be related to direct cell damage, whereas cytokine promoter gene polymorphisms may be related not only to cell damage but also to cell recovery after toxic stress from chemotherapeutic agents. Therefore, we believe that analysis of polymorphisms in gene encoding drug-metabolizing enzymes and cytokines may be useful to predict susceptibility to the toxic effects of anticancer agents. This could help tailor chemotherapeutic regimens to best treat the cancer while minimizing toxic side effects. Because cytokines are related to host reaction to and not metabolism of anticancer agents, our results may be reproducible for other anticancer agents, and therefore, additional studies are needed.

\section{References}

1. Boddy AV and Idle JR: The role of pharmacogenetics in chemotherapy: modulation of tumour response and host toxicity. Cancer Surv 17: 79-104, 1993.

2. Van Kuilenburg AB, Meinsma R, Zoetekouw L and van Gennip AH: Increased risk of grade IV neutropenia after administration of 5-fluorouracil due to a dihydropyrimidine dehydrogenase deficiency: high prevalence of the IVS14+1g>a mutation. Int J Cancer 101: 253-258, 2002.

3. Rouits E, Boisdron-Celle M, Dumont A, Guerin O, Morel A and Gamelin E: Relevance of different UGT1A1 polymorphisms in irinotecan-induced toxicity: a molecular and clinical study of 75 patients. Clin Cancer Res 10: 5151-5159, 2004.

4. Lecomte T, Ferraz JM, Zinzindohoue F, et al: Thymidylate synthase gene polymorphism predicts toxicity in colorectal cancer patients receiving 5-fluorouracil-based chemotherapy. Clin Cancer Res 10: 5880-5888, 2004.

5. Okuda K, Tanaka M, Shibata J, et al: Hepatic arterial infusion chemotherapy with continuous low dose administration of cisplatin and 5-fluorouracil for multiple recurrence of hepatocellular carcinoma after surgical treatment. Oncol Rep 6: 587-591, 1999.

6. Sekiguchi H, Akiyama S, Fujiwara M, et al: Phase II trial of 5-fluorouracil and low-dose cisplatin in patients with squamous cell carcinoma of the esophagus. Surg Today 29: 97-101, 1999. 
7. Tsuji A, Morita S, Horimi T, Takasaki M, Takahashi I and Shirasaka T: Combination chemotherapy of continuous 5-FU infusion and low-dose cisplatin infusion for the treatment of advanced and recurrent gastric and colorectal adenocarcinomas. Gan To Kagaku Ryoho 27: 528-534, 2000.

8. Shirasaka T, Shimamoto Y, Ohshimo H, Saito H and Fukushima M: Metabolic basis of the synergistic antitumor activities of 5-fluorouracil and cisplatin in rodent tumor models in vivo. Cancer Chemother Pharmacol 32: 167-172, 1993.

9. Hirata K, Yamamitsu S, Tsuji A, et al: Biochemical modulation of 5-FU-effect of low dose CDDP. Gan To Kagaku Ryoho 26: $467-475,1999$.

10. Furuhata T, Hirata K, Yamamitsu S, et al: Combination chemotherapy of continuous infusion 5-FU and daily low-dose CDDP in colorectal carcinoma. Gan To Kagaku Ryoho 26: 1554-1558, 1999.

11. Wei X, McLeod HL, McMurrough J, Gonzalez FJ and Fernandez-Salguero P: Molecular basis of the human dihydropyrimidine dehydrogenase deficiency and 5-fluorouracil toxicity. J Clin Invest 98: 610-615, 1996.

12. Van Kuilenburg AB, Vreken P, Beex LV, et al: Heterozygosity for a point mutation in an invariant splice donor site of dihydropyrimidine dehydrogenase and severe 5-fluorouracil related toxicity. Eur J Cancer 33: 2258-2264, 1997.

13. Kouwaki M, Hamajima N, Sumi S, et al: Identification of novel mutations in the dihydropyrimidine dehydrogenase gene in a Japanese patient with 5-fluorouracil toxicity. Clin Cancer Res 4: 2999-3004, 1998.

14. Yamaguchi K, Arai Y, Kanda Y and Akagi K: Germline mutation of dihydropyrimidine dehydrogenese gene among a Japanese population in relation to toxicity to 5-Fluorouracil. Jpn J Cancer Res 92: 337-342, 2001.

15. Le J and Vilcek J: Tumor necrosis factor and interleukin 1: cytokines with multiple overlapping biological activities. Lab Invest 56: 234-248, 1987.

16. Carter DB, Deibel MR Jr, Dunn CJ, et al: Purification, cloning, expression and biological characterization of an interleukin-1 receptor antagonist protein. Nature 344: 633-638, 1990.

17. Taub DD and Oppenheim JJ: Chemokines, inflammation and the immune system. Ther Immunol 1: 229-246, 1994.

18. Okamura $\mathrm{H}$, Tsutsui $\mathrm{H}$, Komatsu $\mathrm{T}$, et al: Cloning of a new cytokine that induces IFN-gamma production by T cells. Nature 378: 88-91, 1995.

19. Swope MD and Lolis E: Macrophage migration inhibitory factor: cytokine, hormone or enzyme? Rev Physiol Biochem Pharmacol 139: 1-32, 1999.

20. Higuchi T, Seki N, Kamizono S, et al: Polymorphism of the 5'flanking region of the human tumor necrosis factor (TNF)-alpha gene in Japanese. Tissue Antigens 51: 605-612, 1998.

21. Ferrari SL, Ahn-Luong L, Garnero P, Humphries SE and Greenspan SL: Two promoter polymorphisms regulating interleukin-6 gene expression are associated with circulating levels of C-reactive protein and markers of bone resorption in postmenopausal women. J Clin Endocrinol Metab 88: 255-259, 2003.

22. Brull DJ, Montgomery HE, Sanders J, et al: Interleukin-6 gene $-174 \mathrm{~g}>\mathrm{c}$ and $-572 \mathrm{~g}>\mathrm{c}$ promoter polymorphisms are strong predictors of plasma interleukin-6 levels after coronary artery bypass surgery. Arterioscler Thromb Vasc Biol 21: 1458-1463, 2001.

23. Takamatsu Y, Akashi K, Harada M, et al: Cytokine production by peripheral blood monocytes and $\mathrm{T}$ cells during haemopoietic recovery after intensive chemotherapy. Br J Haematol 83: 21-27, 1993.

24. Chen YM, Whang-Peng J, Liu JM, Wang SY, Tsai CM and Perng RP: Elevation of serum interleukin- 6 levels before peak of serum granulocyte colony-stimulating factor level in chemotherapy-induced myelosuppressive patients. J Immunother Emphasis Tumor Immunol 17: 249-254, 1995.

25. Chen YM, Whang-Peng J, Liu JM, et al: Serum cytokine level fluctuations in chemotherapy-induced myelosuppression. Jpn J Clin Oncol 26: 18-23, 1996.

26. Bravo L, Legendre AM, Hahn KA, Rohrbach BW, Abraha T and Lothrop CD Jr: Serum granulocyte colony-stimulating factor (G-CSF) and interleukin-1 (IL-1) concentrations after chemotherapy-induced neutropenia in normal and tumor-bearing dogs. Exp Hematol 24: 11-17, 1996.

27. Wang L, Hirayasu K, Ishizawa M and Kobayashi Y: Purification of genomic DNA from human whole blood by isopropanolfractionation with concentrated Nal and SDS. Nucleic Acids Res 22: 1774-1775, 1994.
28. Tarlow JK, Blakemore AI, Lennard A, et al: Polymorphism in human IL-1 receptor antagonist gene intron 2 is caused by variable numbers of an 86-bp tandem repeat. Hum Genet 91: 403-404, 1993.

29. Hamajima N, Saito T, Matsuo K, Kozaki K, Takahashi T and Tajima K: Polymerase chain reaction with confronting two-pair primers for polymorphism genotyping. Jpn J Cancer Res 91: 865-868, 2000.

30. Ye S, Dhillon S, Ke X, Collins AR and Day IN: An efficient procedure for genotyping single nucleotide polymorphisms. Nucleic Acids Res 29: 88, 2001.

31. Okayama N, Fujimura K, Nakamura J, Suehiro Y, Hamanaka Y and Hinoda Y: Evaluation of a new efficient procedure for singlenucleotide polymorphism genotyping: tetra-primer amplification refractory mutation system-polymerase chain reaction. Clin Chem Lab Med 42: 13-16, 2004.

32. Kolb HJ: Bone marrow morbidity of radiotherapy. In: Complications of Cancer Management. Plowman PN, McElwain T and Meadows A (eds). Butterworth-Heineman, Oxford, pp398-411, 1991.

33. Biffl WL, Moore EE, Moore FA, Barnett CC Jr, Carl VS and Peterson VN: Interleukin-6 delays neutrophil apoptosis. Arch Surg 131: 24-30, 1996.

34. Terry CF, Loukaci V and Green FR: Cooperative influence of genetic polymorphisms on interleukin 6 transcriptional regulation. J Biol Chem 275: 18138-18144, 2000.

35. Hsu HC, Tsai WH, Jiang ML, et al: Circulating levels of thrombopoietic and inflammatory cytokines in patients with clonal and reactive thrombocytosis. J Lab Clin Med 134: 392-397, 1999.

36. Kimura H, Ishibashi T, Shikama Y, et al: Interleukin-1 beta (IL-1 beta) induces thrombocytosis in mice: possible implication of IL-6. Blood 76: 2493-2500, 1990.

37. Araneda M, Krishnan V, Hall K, Kalbfleisch J, Krishnaswamy G and Krishnan K: Reactive and clonal thrombocytosis: proinflammatory and hematopoietic cytokines and acute phase proteins. South Med J 94: 417-420, 2001.

38. Fernandez-Real JM, Vendrell J, Richart C, Gutierrez C and Ricart W: Platelet count and interleukin 6 gene polymorphism in healthy subjects. BMC Med Genet 2: 6, 2001.

39. Fishman D, Faulds G, Jeffery R, et al: The effect of novel polymorphisms in the interleukin-6 (IL-6) gene on IL-6 transcription and plasma IL-6 level, and an association with systemic-onset juvenile chronic arthritis. J Clin Invest 102: 1369-1376, 1998

40. Santtila S, Savinainen K and Hurme M: Presence of the IL-1RA allele 2 (IL1RN*2) is associated with enhanced IL-1beta production in vitro. Scand J Immunol 47: 195-198, 1998.

41. Pico JL, Avila-Garavito A and Naccache P: Mucositis: its occurrence, consequences and treatment in the oncology setting. Oncologist 3: 446-451, 1998.

42. Lockhart PB and Sonis ST: Alterations in the oral mucosa caused by chemotherapeutic agents. A histologic study. J Dermatol Surg Oncol 7: 1019-1025, 1981.

43. Guggenheimer J, Verbin RS, Apple BN, et al: Clincopathologic effects of cancer chemotherapeutic agents on human buccal mucosa. Oral Surg Oral Med Oral Pathol 44: 58-63, 1997.

44. Krenger W and Ferrara JL: Graft-vs-host disease and the Th1/ Th2 paradigm. Immunol Res 15: 50-73, 1996.

45. Aggarwal BB, Kohr WS and Hass PE: Human tumor necrosis factor. Production, purification and characterization. J Biol Chem 260: 2345-2354, 1985.

46. Buno IJ, Huff JC, Weston WL, Cook DT and Brice SL: Elevated levels of interferon gamma, tumor necrosis factor alpha, interleukins 2, 4 and 5, but not interleukin 10, are present in recurrent aphthous stomatitis. Arch Dermatol 134: 827-831, 1998.

47. Taylor LJ, Bagg J, Walker DM and Peters TJ: Increased production of tumour necrosis factor by peripheral blood leukocytes in patients with recurrent oral aphthous ulceration. J Oral Pathol Med 21: 21-25, 1992.

48. Wilson AG, Symons JA, McDowell TL, McDevitt HO and Duff GW: Effects of a polymorphism in the human tumor necrosis factor alpha promoter on transcriptional activation. Proc Natl Acad Sci USA 94: 3195-3199, 1997.

49. Bazrafshani MR, Hajeer AH, Ollier WE and Thornhill MH: Recurrent aphthous stomatitis and gene polymorphisms for the inflammatory markers TNF-alpha, TNF-beta and the vitamin D receptor: no association detected. Oral Dis 8: 303-307, 2002. 